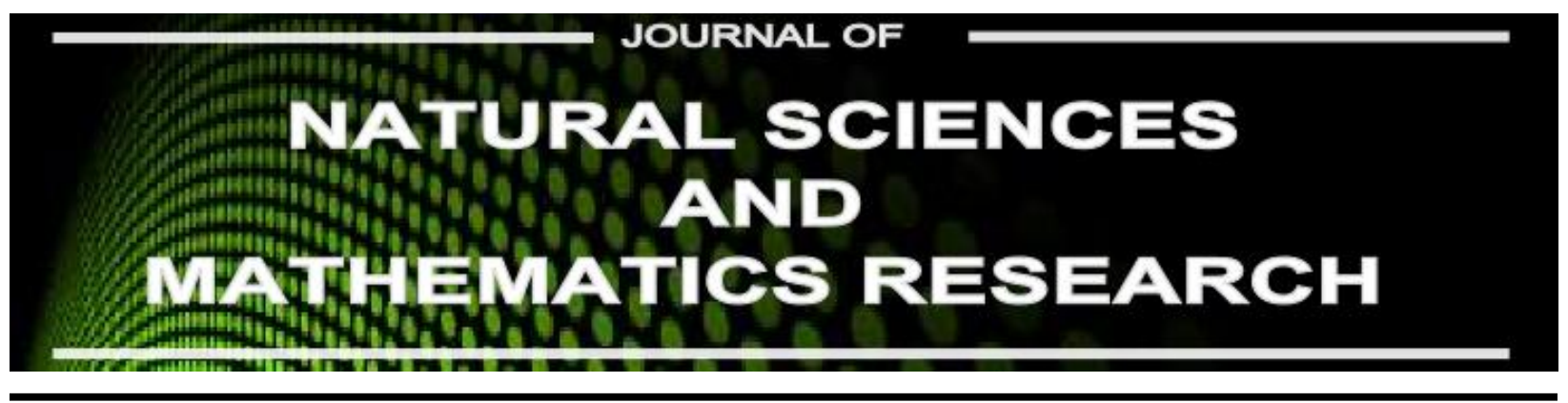

Available online at http://journal.walisongo.ac.id/index.php/jnsmr

\title{
Anti Bacterial Activity of Fungi TIF-1 as Saponin Producer
}

\section{Willy Tirza Eden', Ersanghono Kusumo', Eko Budi Susatyo1, and Kasmui ${ }^{1}$}

1Department of Chemistry, Faculty of Mathematics and Natural Science, Semarang State University, Central Java, Indonesia

\begin{abstract}
s
Corresponding author: willytirzaeden@mail.unne s.ac.id

Recived: 10 November 2016, Revised : 15 December 2016 Accepted: 28 December 2016.

Treatment of microbial resistance is one of humankind's greatest challenges in terms of fight against infectious diseases. One way to overcome microbial resistance is discovery of potent new antimicrobial compounds against variety of microbial pathogens. Land is one potential source of microorganisms. This study aims to screen in order to get a fungal strains isolated from soil exposed to waste the pharmaceutical industry which possess antibacterial activity. Antibacterial activity test conducted on two types of bacteria, namely Staphylococcus aureus as Gram-positive bacteria and Escherichia coli as Gram-negative bacteria. The test results can be known isolates of fungi which has potential as an antibacterial, for then these are fermented for 10 days. Fermented then partitioned by using ethyl acetate. Initial screening showed that the fungi code TIF-1 as the most active fungi. Ethyl acetate soluble fraction was then identified the active compounds using thin layer chromatography method with various reagent spray. Bioautografi test results show that the saponins which play role in the antibacterial activity. (C)2016 JNSMR UIN Walisongo. All rights reserved.
\end{abstract}

Key words: Antibacterial Agent; Soil Fungi; Saponin

\section{Introduction}

One of health world glory is development of antibiotic and other anti microbe agent. However, the expanded of resistance by target microbe is a increasing concern [1]. it is big challenge for human being in term of against the infection disease in the beginning of $21^{\text {th }}$ century. Microbe resistance is condition where a microorganism (bacteria, virus, and many parasite) change of this sort so is caused previous medicine used to treat infection become not effective. From year to year, the quantity case as a consequence of microbe resistance toward antibiotic is more rise [3].

According to result report of anti microbe resistance supervision 22 state in Europe, there is an increasing of infection amount in blood by Escherichia coli bacteria as big as 71\% (from 688 case become 18240 case), and by Staphylococcus aureus bacteria as big as 34\% (from 7855 case become 10503 case) 
during year period of 2002-2009. On that period, it is also gain increasing of E. coli amount that resistant towards sefalosporin third generation from 1,7\% become $8 \%$ from total infection case in blood [4].

The wisely usage of antibiotic (the proper drug usage in dosage and right giving time) is one of an important way to reduce the appear of resistance organism [5]. Germ resistance toward antibiotic can complicate the medical personnel in disease medical treatment process, for example efflorecse of Salmonella typhimurium bacteria and Salmonella kentucky that resistance toward sefaloporins [6], Staphylococcus aureus bacteria that resistance toward methicillin or called MRSA (Methicillin resistant Staphylococcus aureus) [7] or resistance of Pseudomonas aeruginosa bacteria toward getamicin antibiotic, tobramycin, and amikacin that called MARPA (multiple antibiotic-resistant Pseudomonas aeruginosa) [8]. Because of that, it is needed an effort to get new antibiotic species whether through chemical synthesis, biochemical, or invention of new microbe isolat as producer of antibiotic.

The waste handling is a serious environment problem in many cities in the world. The waste that produced in the form of chemical or biological waste. Those waste usually only threw away in the ground. Excessive disposal of Chemical and biological waste probability can influence physic and chemical character of land. Various research have been done to know the effect of waste excessive toward physic-chemical-biochemical character, productivity, microbe population, enzyme activity and plant growth in the land. For example, food waste excessive can cause increasing of land enzyme activity that come from microorganism on the land if it compare with commercial compost fertilizer and mineral fertilizer [9-11]. Research that is done by Lebkoswka et all [12] said that microorganism which is isolated from the polluted land of fuel increase bioremediasi effectiveness land as many as $30-50 \%$. other research that is done by Karamalidid et all [13] also said that giving microorganism of isolated result from polluted land then add mixing can relieve concentrate of n-alkana to $94 \%$ and 16 compound of aromatic polisklik until $74 \%$.

Source exploration of new antibiotic often used medicine plant that the existence is more less because there is to much exploited without re-plant of the medicine plant. Planting the medicine plants need long time until harvest time, so the producer or researcher become difficult in supply basic material. In this research, fungi is isolated from the excessive land of chemical waste in one pharmacy industry in Semarang city and it will be researched the fungi anti bacteria activity from land isolated result and also group of anti microbe compound used KLT-bioautografi. The result can be long research as new antibiotic.

\section{Experiments Procedure}

\section{Isolation of Fungi from land}

One gram of land sample near the pharmacy industry that polluted by waste is suspension in $10 \mathrm{~mL}$ of saline solution in sterile tube then liquid until concentrate of $10^{-}$ 2. And then $0,5 \mathrm{~mL}$ suspension is poured to sterile tube consist of solid selective media PDA that contain antibiotic, it is flat used spreader glass then incubation until growth the fungi colony.

\section{Purifying of Fungi culture}

Fungi colony is moved from growth result media of land microbe sample to the new PDA. The movement is done by aseptic used ose. Petri dish is sealed and incubated in room temperature more over 7 days until seen the growth of clear and pure of fungi colony.

\section{Screening the anti bacteria activity}

Pure fungi culture is tested the activity toward Escherichia coli and Staphylococcus aureus. Testing is done with method of solid diffusion. After incubation, there is obstacle zone that formed around the fungi culture. There is clear area formed shows that the fungi can obstruct the bacteria growth on medium test. 


\section{Production of seconder metabolite}

The chosen fungi culture is fermented in PDB medium in simple fermentor in the form of Erlenmeyer have content $250 \mathrm{~mL}$ of PDB medium. Filtrate that produced is received, filtered, and liquid extracted used ethyl asetat with comparison medium : ethyl asetat $=2: 1$ as many as three time partition. Extract of ethyl asetat that produced is collected and let it evaporate in acid case until dry.

\section{Identification of antibacteria active compound}

Extract of ethyl asetat is tested by thin layer kromatography - bioautography contact. Spotted that have anti bacteria activity is identify the compound group used reagen spry that is dragendorff, ferri chloride, vanilin-asam sulfat, anisaldehid-asam sulfat, and alumunium chloride.

\section{Results and Discussion}

Land sample which is taken is land in area of drainage flow of pharmacy industry liquid waste. Land on the area is moist and the optimal living place for fungi. Land suspension in physiology $\mathrm{NaCl}$ solution is liquid until obtain concentration of $10^{-2}$, where is previously conducted without dilution and dilution of $10^{-1}$, however the fungi is growth not optimum and more bacterial grow. Physiology $\mathrm{NaCl}$ is used because osmosis pressure and optimum isotonic content for microorganism growth including fungi. PDA that contain antibiotic used for microorganism of isolation result from growing land is fungi without bacteria contamination. PDA is good medium for fungi or kapng growth. Before using PDA, researcher doing isolation used Nutrient Agar (NA) medium, however those medium is not selective to growth fungi.

Culture purifying is done to produce pure fungi colony, which signed with the growth of one kind of fungi for one petri dish. Isolation which is done before is produced 2 fungi with different character, so culture purifying is done to new PDA medium for 2 kind of fungi. The two culture is given code of TIF- 1 and TIF-2. Culture morphology character of fungi TF-1 is white color as cotton, white color of spore (see the Figure 1), while Culture morphology character of fungi TF-2 is dark brown color, spore resemble of color dark brown dust (see the Figure 2).

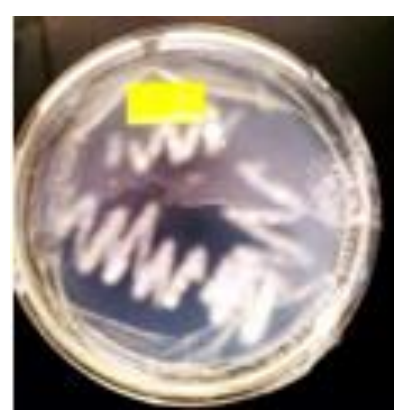

Figure 1. Fungi Culture of TIF-1

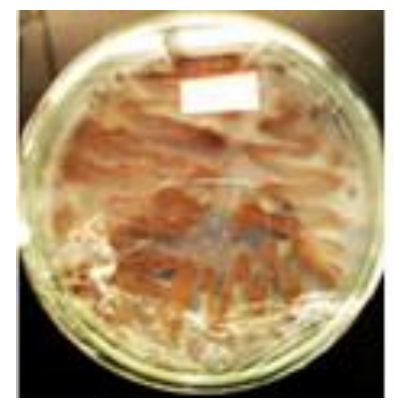

Figure 2. Fungi Culture of TIF-2

Screening of anti bacteria activity is done to know the anti bacteria potential of each isolated result fungi. Method that is used is agar diffusion method, 1 plug for each fungi is transferred to medium that is content of bacteria. In this case, the bacteria that used is Escherichia coli and Staphylococcus aureus. Screening of anti bacteria activity is done with three time replica. Based on screening activity result toward fungi culture of TIF-1 and TIF-2 get result that both fungi have anti bacteria activity toward Eschericia coli and Staphylococcus aureus (see the Figure 3), however strain fungi of TIF-1 have biggest activity is compared with strain fungi of TIF- 2 . Fungi TIF-1 produced blocked zone as big as 1.6 $\mathrm{cm}$ at Staphylococcus aureus bacteria and 1,15 $\mathrm{cm}$ Eschericia coli bacteria. While fungi TIF-2 produced blocked zone as big as $0.55 \mathrm{~cm}$ at 
Staphylococcus aureus bacteria and $0.96 \mathrm{~cm}$ Escherichia coli bacteria.
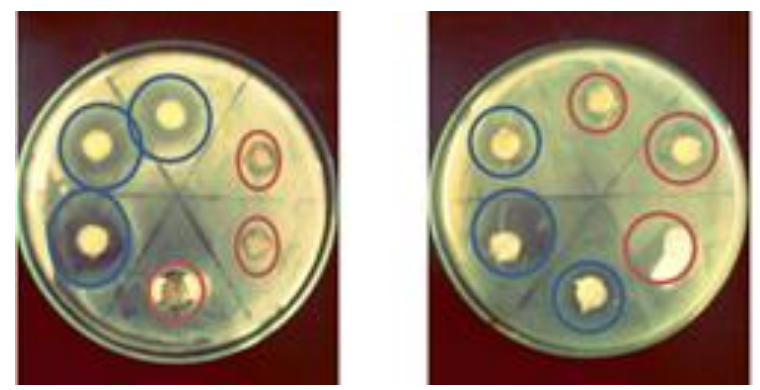

Figure 3. Activity of fungi anti bacteria of TIF-1 (blue) and fungi of TIF-2 (red), medium of Staphylococcus aureus (left) and Escherichia coli (right)

Fungi fermentation of TIF-1 is done on PDB medium because PDB medium have same nutrition with PDA medium. PDB medium guarantee fungi that fermented produced product or compound that is same with the fungi which growth in the PDA medium. Fermentation is set up in incubator until fungi enter the stationer which signed with the amount of fungi that is not increase. This phase needs time during 10 days (see Figure 4).

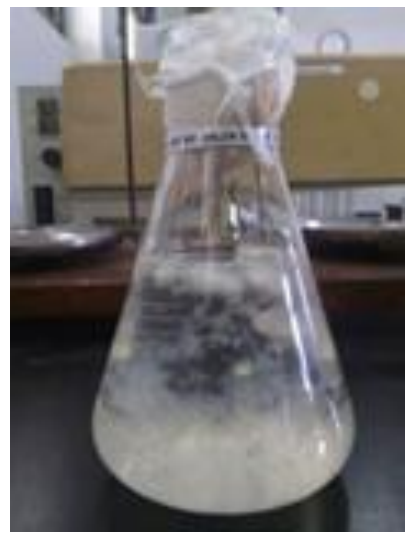

Figure 4. Fermentation of Fungi TIF-1

Removal of fermentation metabolite is done by filtering to separated medium with fungi cell. Filtrate then liquid extracted by used ethyl asetat which have semi polar character. Fraction of ethyl asetat is evaporated in the open air until get thick fraction. Evaporation time is need as long as 13 days and fraction is pale yellow color.

KLT-Bioautografi slab that is used is silica gel $\mathrm{GF}_{254}$ and moving phase of n-heksana : Chloroform : asetat acid (1: $8.9: 0.1$ ). it is produced 2 spotted from splatter as many as $2 \mu \mathrm{l}$ of ethyl asetat fraction with each $\mathrm{Rf}$ as big as 0.25 and 0.675 , its produced fluorosensi of pale violet under UV ray of $254 \mathrm{~nm}$. Spot show the anti bacteria activity is spot with hRf value is 67.5. But the hamper zone that appear is in inoculation of Staphylococcus aureus bacteria, while in Escherichia coli bacteria is not show the hamper zone (see Figure 5). Identification of active compound is done used 5 kinds of spot. It is understanding that spot with hRf 67.5 is positive saponin which is proved with the formed of yellow brown color after sprayed with vanilin- sulfate acid (see the Figure 6) .
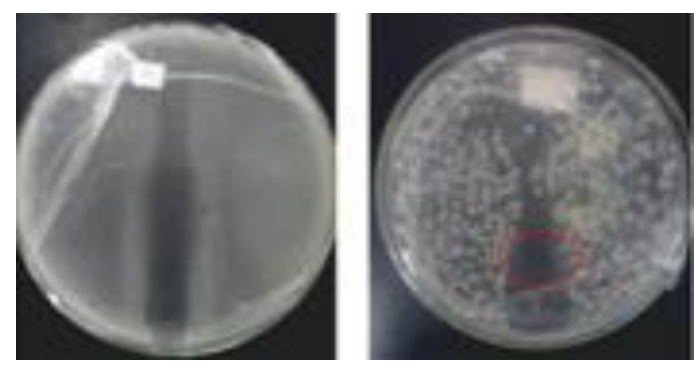

Figure 5. KLT-Bioautograf fraction of ethyl asetat of TIF-1 fungi culture. Medium of Escherichia coli (left) and Staphylococcus aureus (right). value of hRf 67,5 (red circle)

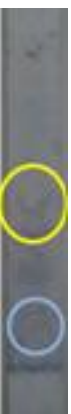

Figure 6. KLT slab after sprayed by Vanilin- Sulfate Acid. Value of hRf 25 (blue circle) and hRf 67,5 (yellow circle) 


\section{Conclusion}

Land that contaminated with pharmacy industry waste in Semarang city contain fungi. Fungi of TIF- 1 and TIF- 2 as isolation result have anti bacteria activity toward Eschericia coli and Staphylococcus aureus with biggest anti bacteria activity is produced by fungi TIF-1. Saponin compound probability have role in anti bacterial activity of fraction ethyl asetat of fungi TIF-1.

\section{Acknowledgment}

The authors would like to Department of Chemistry, Faculty of Mathematics and Natural Science, Semarang State University, for financialsupport.

\section{References}

[1] G.J. Tortora, B.R. Funke, C.L. Case, Microbiology: An Introduction, 10th ed., 554-579, 758-759, Pearson Benjamin Cummings, San Fransisco. , 2010.

[2] S. Hogg, Essential Microbiology, 365, John Wiley \& Sons, Chichester, 2005.

[3] S.P. Denyer, N.A. Hodges, S.P. Gorman, , Hugo and Russell's Pharmaceutical Microbiology, 7th ed., 220-232, Blackwell Science, Victoria, 2004.

[4] Anonim, Surveillance Report: Antimicrobial Resistance Surveillance in Europe 2009, European Centre for Disease Prevention and Control (ECDC), Stockholm, 2010.

[5] S.T. Pratiwi, Mikrobiologi Farmasi, 154, 114-117, 188-192, Penerbit Erlangga, Jakarta, 2008.

[6] T. Mohamed, S. Zhao, D.G. White, and S. Parveen, Molecular characterization of antibiotic resistant Salmonella typhimurium and Salmonella kentucky isolated from pre- and post-chill whole broilers carcasses. Food Microbiology, 38: pp. 6-15, 2014.

[7] M. Iwamoto, Y. Mu, R. Lynfield, S.N. Bulens, J. Nadle, D. Aragon, D., Trends in invasive methicillin-resistant Staphylococcus aureus infections. Pediatrics, 132: pp. e817-824, 2013.
[8] C.L. Ren, M.W. Konstan, A. Yegin, L. Rasouliyan, B.Trzaskoma, W.J. Morgan, Multiple antibiotic-resistant Pseudomonas aeruginosa and lung function decline in patients with cystic fibrosis. Journal of Cystic Fibrosis, 11. pp. 293-299, 2012.

[9] M.A.N. Anikwe, K.C.A. Nwobodo, Long term effect of Municipal waste disposal on soil properties and productivity of sites used for urban agriculture in Abakaliki, Nigeria, Bioresource Technology, 83, pp. 241-250, 2002.

[10] C. Crecchio, M. Curci, M.D.R. Pizzigallo, P. Ricciuti, P. Ruggierio, Effects of municipal solid waste compost amendments on soil enzyme activities and bacterial genetic diversity, Soil Biology \& Chemistry, 36, pp. 1595-1605, 2004.

[11] J.J. Lee, R.D. Park, Y.W. Kim, J.H. Shim, D.H. Chae, Y.S. Rim, B.K. Sohn, T.H. Kim, K.Y. Kim, Effect of food waste compost on microbial population, soil enzyme activity and lettuce growth, Bioresource Technology, 93, pp.21-28, 2004.

[12] M. Lebkowska, E. Zborowska, E. Karwowska, E. Miaskiewicz-Peska, A. Muszynski, A. Tabernacka, J. Naumczyk, M. Jeczalik, Biremediation of soil polluted with fuels by sequential multiple injection of native microorganism: Field-scale processes in Poland, Ecological Engineering, 37, pp.1895-1900, 2011.

[13] A.K. Karamalidis, A.C. Evangelou, E. Karabika, A.I. Koukkou, C. Drainas, E.A. Voudrias, Laboratory scale bioremediation of petroleum-contaminated soil by indigenous microorganisms and added Pseudomonas aeruginosa strain Spet, Bioresource Technology, 101, pp. 65456552, 2010. 